\title{
Calcinosis cutis mimicking xanthoma: A case report
}

\author{
Balachandra S Ankad', Arun T Miskin², Mahantesh K Math³, Punit S Sakhare \\ ${ }^{1}$ Department of Dermatology, S N Medical College, Bagalkot, Karnataka, India, ${ }^{2}$ Department of Pathology, S N Medical \\ College, Bagalkot, Karnataka, India, ${ }^{3}$ Sai Plastic Surgery Center, Bagalkot, Karnataka, India
}

Corresponding author: Dr. Balachandra S Ankad, E-mail: drbsankad@gmail.com

Calcinosis cutis (CC) is deposition of calcium salts in the skin. It is of four types i) dystrophic, ii) metastatic, iii) idiopathic and iv) iatrogenic [1]. Idiopathic CC is cutaneous calcification of unknown cause with normal serum calcium. Subepidermal calcified nodule and tumoral calcinosis are idiopathic forms of calcification [2].

Here authors present a case of idiopathic CC mimicking as xanthoma. A 45 year female presented with asymptomatic lesion on the right cheek for the past 8 months. There was no history of trauma or preexisting skin lesion. On examination, yellowish plaque with rough surface and irregular but well defined borders (Fig. 1). There were no similar lesions elsewhere on the body. Xanthoma and solar elastolysis were considered as differentials. Laboratory investigation revealed normal blood analysis including lipid profile. Skin biopsy was done and it was not suggestive of either xanthoma or solar elastolysis. Tissue was stained with Von Kossa for calcium salts (Fig. 2). Presence of calcium deposits

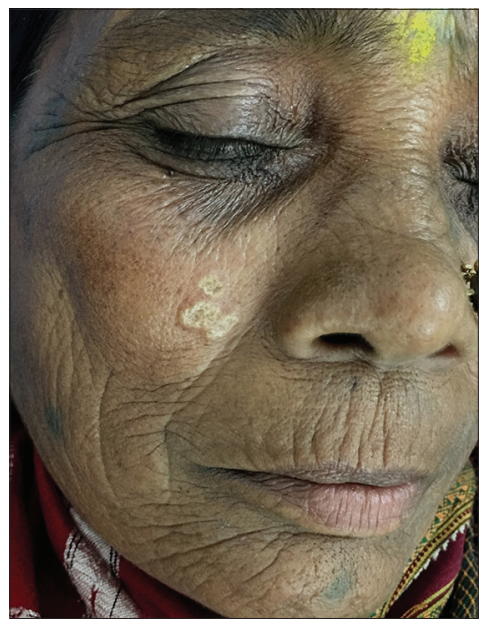

Figure 1: Yellowish plaque on the right cheek. was ascertained and provisional diagnosis of $\mathrm{CC}$ was made. Relevant investigations were carried out to know the cause of CC. Serum calcium, phosphate, and parathyroid hormone levels were normal. Based on the biochemical analysis and histopathology, idiopathic $\mathrm{CC}$ was made. Excision was done without recurrence (Fig. 3). Commonly, CC presents as chalky white plaque wherein diagnosis of $\mathrm{CC}$ is predictable [3]. Yellowish color of the lesion was misleading the scenario in this case. Hence, when asymptomatic yellowish plaque is encountered, CC should also be kept in differentials with xanthoma.

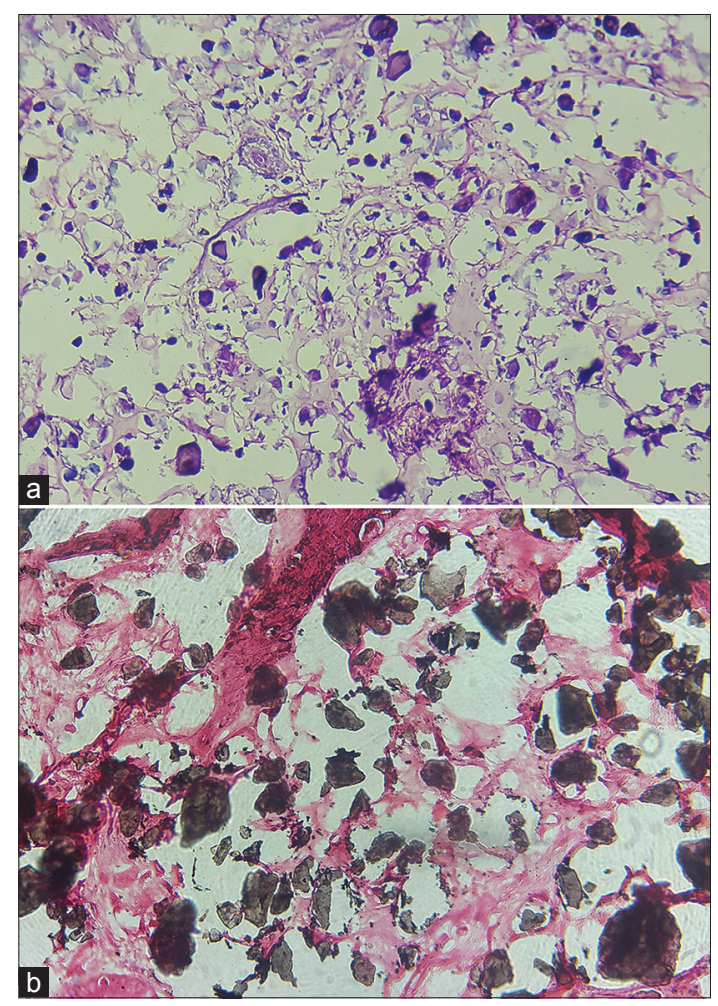

Figure 2: Calcium deposits in the dermis. (Panel 'a'10x, H \& E) and calcium deposits with Von Kossa (Panel 'b' 40x).

\footnotetext{
How to cite this article: Ankad BS, Miskin AT, Math MK, Sakhare PS. Calcinosis cutis mimicking xanthoma: A case report. 2018;9(1):95-96. Submission: 02.02.2017; Acceptance: 21.10.2017 DOI: $10.7241 /$ ourd.20181.30
} 
www.odermatol.com

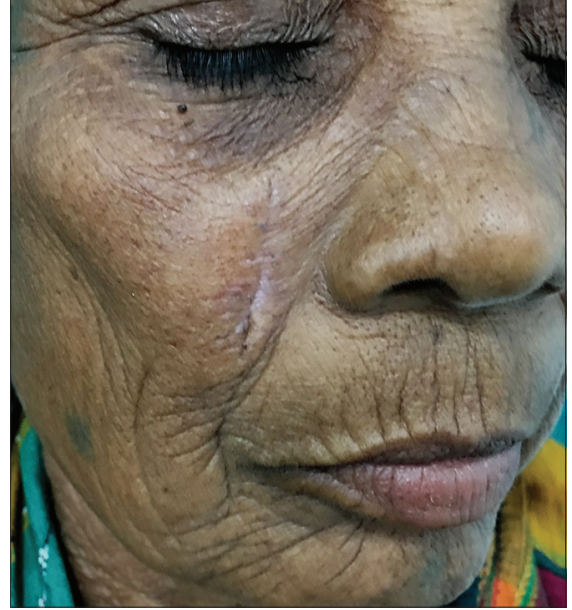

Figure 3: Post operative scar good healing.

This case is reported because of yellowish color which was mimicking xanthoma.

\section{Consent}

The examination of the patient was conducted according to the Declaration of Helsinki principles.

\section{REFERENCES}

1. Muddegowda PH, Lingegowda JB, Ramachandrarao RK, Konapur PG. Calcinosis Cutis: Report of 4 Cases. J Lab Physicians. 201;3:125-6.

2. Sardesai VR, Gharpuray MB. Calcinosis cutis. Indian J Dermatol Venereol Leprol. 2003;69:45-6.

3. Kayhan TC, Temiz P, Ermertcan AT. Calcinosis cutis on the face. Indian J Dermatol Venereol Leprol. 2009;75:180-1.

Copyright by Balachandra S Ankad, et al. This is an open-access article distributed under the terms of the Creative Commons Attribution License, which permits unrestricted use, distribution, and reproduction in any medium, provided the original author and source are credited.

Source of Support: Nil, Conflict of Interest: None declared. 